\title{
Perception of Scientists on Performance Indicators for Monitoring and Evaluation of Agricultural Research System of India
}

\author{
Chandan Kumar Panda ${ }^{1 *}$, Arun Kumar ${ }^{2}$, Vishal Tripathi ${ }^{3}$ and Siya Ram Singh ${ }^{1}$ \\ ${ }^{1}$ Department of Extension Education, ${ }^{2}$ Director Planning \& Dean (Agriculture), \\ ${ }^{3}$ Department of Horticulture (Vegetable \& Floriculture), Bihar Agricultural University, \\ Sabour, Bhagalpur - 813 210, India
}

*Corresponding author

\section{A B S T R A C T}

\section{Keywords \\ Faculties, Agricultural University, Quality}

Article Info

Accepted:

10 September 2018

Available Online:

10 October 2018
Continuous Monitoring \& Evaluation (M\&E) of Agricultural Research System of India (ARSI) is done regularly. However, time to time the performance indicators for M\&E of ARSI need to be revalidated and new indicators to be incorporated. Keep this in mind, this research programme was conducted. Based on the result, the indicators are faculty associated with the international collaboration in research, $\%$ of staff involved as principal researcher in external funded project, addressing the current research problem of farmers, $\mathrm{MoU} / \mathrm{MoA}$ and collaboration with the industries, international joint research publications, patent awarded to university, expenditure on research.

\section{Introduction}

The economic performance of the agricultural sector in the most of the countries has been largely determined by the organised research. State Agricultural Universities (SAUs) and Central Agricultural Universities (CAUs) of India have a mandate of doing research along with teaching and extension. The agricultural universities are greatly contributing for development of new technologies for the farming communities. However, the performance of Agricultural Research System largely depends on resource allocation and long-term goal planning, structure and organization of research system, linkage between National Agricultural Research Systems (NARS) and policy-makers, external sources of knowledge and collaboration, programme formulation and programme budgeting, monitoring and evaluation, information management, development and management of physical resources, and; acquisition and management of financial resources etc. (ISNAR, 1987). According Ranjitha (1998) National Agricultural Research Systems (NARS) need changes in relation to human resource development, organization and management reforms, funding, basic and strategic research, 
planning, monitoring and evaluation. Indian Council of Agricultural Research (ICAR)Agricultural Universities (AUs) system comprising of sixty State Agricultural Universities, five Deemed to be Universities, three Central Agricultural University and four Central Universities with Agriculture Faculty. Faculties/scientists of these universities contribute in agricultural research of the NARS. However, the performance of these universities' research needs to be monitor regularly through the set of indicator. These are coined as 'Performance Indicators' for Monitoring and Evaluation of Agricultural Research System of India. Institutional and national quality models and performance indicators are considered vital components in raising the research standard (Marginson and Van der Wende 2007). Under this backdrop, this research work was undertaken with the objectives to identify and validate the Performance Indicators for Monitoring and Evaluation of Agricultural Research System of India.

\section{Materials and Methods}

Times Higher Education (THE), Academic Ranking of World Universities (ARWU), UMultirank, Higher Education Evaluation and Accreditation Council of Taiwan (HEEACT), Australian Universities Ranking; National Institute Ranking Framework in India; ICAR Agricultural University Ranking etc. conduct ranking of universities based on set of performance indicators. For present study, indicators of aforesaid agencies were reviewed and exhaustive lists of performance indicators were made. Finally, through expert judgement the scale was developed. Five point Likert Scale was used for recording the response/perception of the respondents. For the study, data was collected from 250 faculties of twenty two agricultural universities across India. Among these respondents 126, 33 and 91 were Assistant
Professor, Associate Professor and University Professor respectively. The period of data collection was January to February, 2017.

\section{Formula for selection of Indicators}

Mean value for Assistant Professor response is symbolised as $\mathrm{M}_{1}$

Mean value for Associate Professor response is symbolised as $\mathrm{M}_{2}$

Mean value for Professor response is symbolised as $\mathrm{M}_{3}$

Mean value for altogether response is symbolised as $\mathrm{M}_{4}$

Criteria for selection of a specific indicator:

$\mathrm{M}_{1}=\mathrm{M}_{2}=\mathrm{M}_{3}=\mathrm{M}_{4}=2$ or more (Criteria 1)

$\mathrm{M}_{1}=\mathrm{M}_{2}=\mathrm{M}_{3}=2$ or more (Criteria 2)

$\mathrm{M}_{1}=\mathrm{M}_{2}=\mathrm{M}_{4}=2$ or more (Criteria 3)

$\mathrm{M}_{2}=\mathrm{M}_{3}=\mathrm{M}_{4}=2$ or more (Criteria 4$)$

If any of the listed $2 \mathrm{~s}$ indicators (Table 5) satisfied any one of the aforesaid criteria, it was selected for the monitoring and evaluation of agricultural Education System of India in the study.

\section{Results and Discussion}

From the Table 1 , it is noted that $50.40 \%$, $36.40 \%$ and $13.20 \%$ respondents were Assistant Professor, Professor and Associate Professor. It was also noted that altogether (Assistant Professor, Associate Professor and Professor), the respondents' mean experience is 17.372 years with SD 10.110 (Table 2).

The alpha coefficient for the 25 indicators (Table 3) is 0.925 (Assistant Professor), 0.949 (Associate Professor), 0.946 (Professor) and 0.936 (Altogether) respectively and suggesting that the items have relatively high internal 
consistency (A reliability coefficient of 0.70 or higher is considered "acceptable" in most social science research situations).

Taking the experiences of the respondents as dependent variable and remaining 24 indicators as independent variables, regression analysis was conducted and it was noted that $\mathrm{R}$ Square was 0.668 which implied that altogether all those indicators explained 66.80 $\%$ variation in the model (Table 4 ).

Table.1 Distribution of respondents (teachers/scientists) as per their designation

\begin{tabular}{|c|c|c|c|}
\hline SI. No. & Designation & $f$ & Per cent \\
\hline 1. & Assistant Professor & 126 & 50.40 \\
\hline 2. & Associate Professor & 33 & 13.20 \\
\hline \multirow[t]{2}{*}{3.} & Professor & 91 & 36.40 \\
\hline & Total & 250 & 100.00 \\
\hline
\end{tabular}

Table.2 Distribution of the respondents according to their teaching and research experience

\begin{tabular}{|l|l|c|c|}
\hline $\begin{array}{l}\text { SI. } \\
\text { No. }\end{array}$ & Categories & Mean & SD \\
\hline 1. & Assistant Professor & 10.992 & 7.866 \\
\hline 2. & Associate Professor & 18.121 & 7.139 \\
\hline 3. & Professor & 26.34 & 6.412 \\
\hline 4. & $\begin{array}{l}\text { Altogether (Asst.Prof + Assoc.Prof. + } \\
\text { Prof.) }\end{array}$ & 17.372 & 10.11 \\
\hline
\end{tabular}

Table.3 Reliability statistics of the Scale

\begin{tabular}{|l|l|c|}
\hline SI. No. & Categories & Cronbach's alpha \\
\hline 1. & Assistant Professor & 0.925 \\
\hline 2. & Associate Professor & 0.949 \\
\hline 3. & Professor & 0.946 \\
\hline 4. & Altogether & 0.936 \\
\hline
\end{tabular}

Table.4 Model Summary

\begin{tabular}{|l|r|r|r|r|}
\hline Model & \multicolumn{1}{|l|}{ R } & R Square & \multicolumn{1}{|c|}{$\begin{array}{c}\text { Adjusted R } \\
\text { Square }\end{array}$} & $\begin{array}{l}\text { Std. Error of } \\
\text { the Estimate }\end{array}$ \\
\hline 1 & .668 & .447 & .078 & 9.52935 \\
\hline
\end{tabular}


Table.5 Indicators for monitoring and evaluation of Agricultural Research System of India

\begin{tabular}{|c|c|c|c|c|c|c|c|c|c|c|}
\hline \multirow[b]{3}{*}{$\begin{array}{l}\text { Sl. } \\
\text { No. }\end{array}$} & \multirow[b]{3}{*}{$\begin{array}{l}\text { Indicators } \\
\text { (1) }\end{array}$} & \multicolumn{8}{|c|}{ Respondents categories with their Mean \& SD } & \multirow{3}{*}{$\begin{array}{l}\text { Remark on } \\
\text { validation of } \\
\text { Indicator } \\
\text { (Selected/ } \\
\text { Rejected) } \\
\text { (10) }\end{array}$} \\
\hline & & \multicolumn{2}{|c|}{$\begin{array}{l}\text { Asst. Professor (A) } \\
\qquad\left(n_{1}=126\right)\end{array}$} & \multicolumn{2}{|c|}{$\begin{array}{l}\text { Assoc. Professor } \\
\text { (B) }\left(\mathbf{n}_{2}=33\right)\end{array}$} & \multicolumn{2}{|c|}{$\begin{array}{l}\text { Professor } \\
\text { (C) }\left(\mathbf{n}_{3}=91\right.\end{array}$} & \multicolumn{2}{|c|}{$\begin{array}{c}\text { Altogether } \\
(A+B+C)\left(n_{4}=250\right)\end{array}$} & \\
\hline & & $\begin{array}{c}\text { Mean } \\
\left(\mathbf{M}_{1}\right) \\
(2)\end{array}$ & $\begin{array}{l}\text { SD } \\
(3)\end{array}$ & $\begin{array}{l}\text { Mean(M } \\
\text { 2) } \\
\text { (4) }\end{array}$ & $\begin{array}{l}\text { SD } \\
(5)\end{array}$ & $\begin{array}{c}\text { Mean( } \\
\left.\mathbf{M}_{3}\right) \\
(6)\end{array}$ & $\begin{array}{l}\text { SD } \\
(7)\end{array}$ & $\begin{array}{c}\text { Mean( } \\
\left.\mathbf{M}_{4}\right) \\
(8)\end{array}$ & SD & \\
\hline 1 & $\begin{array}{l}\text { No. of faculty associated with the } \\
\text { international collaboration in research }\end{array}$ & 2.031 & 0.902 & 2.181 & 0.882 & 2.120 & 0.892 & 2.084 & 0.894 & Selected \\
\hline 2 & $\begin{array}{l}\% \text { of staff involved as principal researcher } \\
\text { in external funded project }\end{array}$ & 2.039 & 0.741 & 2.333 & 0.816 & 2.109 & 0.721 & 2.104 & 0.747 & Selected \\
\hline 3 & $\begin{array}{l}\text { Speed of university departments' response } \\
\text { to current research problem of farmers }\end{array}$ & 2.333 & 0.715 & 2.531 & 0.717 & 2.450 & 0.719 & 2.401 & 0.717 & Selected \\
\hline 4 & $\begin{array}{l}\text { No. of multi-departmental external funded } \\
\text { Project running }\end{array}$ & 2.127 & 0.779 & 2.281 & 0.851 & 2.153 & 0.815 & 2.156 & .800 & Selected \\
\hline 5 & $\begin{array}{l}\text { Recognition in the scientific community } \\
\text { of the work produced by university } \\
\text { departments }\end{array}$ & 2.232 & 0.773 & 2.354 & 0.797 & 2.263 & 0.800 & 2.259 & 0.784 & Selected \\
\hline 6 & $\begin{array}{l}\text { Number of active national/ international } \\
\text { MoU/ MoA and collaboration with the } \\
\text { industries }\end{array}$ & 2.056 & 0.826 & 2.156 & 0.846 & 2.076 & 0.833 & 2.076 & 0.828 & Selected \\
\hline 7 & $\begin{array}{l}\text { Number of international joint research } \\
\text { publications }\end{array}$ & 1.896 & 0.901 & 2.000 & 0.915 & 2.111 & 0.953 & 2.085 & 0.924 & Selected \\
\hline 8 & $\begin{array}{l}\text { Number of international research project } \\
\text { received }\end{array}$ & 1.824 & 0.942 & 2.069 & 0.918 & 2.011 & 0.965 & 2.011 & 0.948 & Selected \\
\hline 9 & Number of postdoctoral positions & 1.722 & 0.926 & 1.939 & 0.933 & 1.681 & 0.880 & 1.736 & 0.910 & Rejected \\
\hline 10 & $\begin{array}{l}\text { Research Excellence (No. of research } \\
\text { articles in high impact journals (NAAS } \\
\text { rating of over } 7.0 \text { in } 5 \text { years) }\end{array}$ & 2.112 & 0.881 & 2.242 & 0.791 & 2.285 & 0.792 & 2.192 & 0.833 & Selected \\
\hline 11 & $\begin{array}{l}\text { Research Impact (No. of papers cited } 20 \\
\text { times or more each in last } 5 \text { years) }\end{array}$ & 2.121 & 0.822 & 2.093 & 0.683 & 2.269 & 0.779 & 2.171 & 0.791 & Selected \\
\hline 12 & Research Journal Published by institute & 1.888 & 0.863 & 1.969 & 0.809 & 1.835 & 0.859 & 1.879 & 0.852 & Rejected \\
\hline 13 & Research database in university website & 2.016 & 0.775 & 2.181 & 0.768 & 2.000 & 0.930 & 2.032 & 0.833 & Selected \\
\hline 14 & $\begin{array}{l}\text { Availability of PME (Prioritization, } \\
\text { Monitoring \& Evaluation) cell in the } \\
\text { university }\end{array}$ & 1.991 & 0.811 & 2.093 & 0.928 & 2.022 & 0.820 & 2.016 & 0.827 & Selected \\
\hline 15 & $\begin{array}{l}\text { Number of edited or co-authored books } \\
\text { published by the faculty of the institute }\end{array}$ & 2.032 & 0.717 & 2.090 & 0.630 & 2.088 & 0.713 & 2.060 & 0.703 & Selected \\
\hline 16 & $\begin{array}{l}\text { Number of articles published in peer- } \\
\text { reviewed journals }\end{array}$ & 2.280 & 0.616 & 2.303 & 0.769 & 2.362 & 0.691 & 2.313 & 0.664 & Selected \\
\hline 17 & $\begin{array}{l}\text { Number of monographs published by } \\
\text { well-regarded publishing houses }\end{array}$ & 1.774 & 0.872 & 1.937 & 0.715 & 2.000 & 0.738 & 1.877 & 0.810 & Rejected \\
\hline 18 & $\begin{array}{l}\text { Number of international awards and } \\
\text { prizes won for research work }\end{array}$ & 2.137 & 0.875 & 2.000 & 0.901 & 2.175 & 0.914 & 2.133 & 0.854 & Selected \\
\hline 19 & $\begin{array}{l}\text { Research Excellence (Varieties released, } \\
\text { Breeder Seed demand thereof, Area } \\
\text { Covered, products developed, traits } \\
\text { identified and its economic impact, breed } \\
\text { developed, technologies developed) }\end{array}$ & 2.371 & 0.770 & 2.437 & 0.800 & 2.670 & 0.558 & 2.489 & 0.714 & Selected \\
\hline 20 & Patent awarded to university & 2.161 & 0.849 & 2.125 & 1.039 & 2.263 & 0.814 & 2.194 & 0.861 & Selected \\
\hline 21 & Total number of patents pending & 1.758 & 0.925 & 1.781 & 1.069 & 1.988 & 0.915 & 1.837 & 0.925 & Rejected \\
\hline 22 & $\begin{array}{l}\text { Research fund received from national and } \\
\text { international institution }\end{array}$ & 2.219 & 0.741 & 2.312 & 0.780 & 2.230 & 0.731 & 2.235 & 0.740 & Selected \\
\hline 23 & $\begin{array}{l}\text { Proportion of funds (for example, } \\
\text { royalties) received by university } \\
\text { departments through licence fees for } \\
\text { intellectual property }\end{array}$ & 1.788 & 0.831 & 1.806 & 0.980 & 1.955 & 0.923 & 1.852 & 0.885 & Rejected \\
\hline 24 & $\begin{array}{l}\text { Proportion of university department funds } \\
\text { derived from research contracts with } \\
\text { companies }\end{array}$ & 1.804 & 0.846 & 1.727 & 0.910 & 1.934 & 0.840 & 1.842 & 0.852 & Rejected \\
\hline 25 & Expenditure on research & 2.264 & 0.716 & 2.354 & 0.797 & 2.297 & 0.740 & 2.288 & 0.733 & Selected \\
\hline
\end{tabular}


On the basis of aforesaid formula as stated in methodology (i.e. $M_{1}=M_{2}=M_{3}=M_{4}=2$ or more; $\mathrm{M}_{1}=\mathrm{M}_{2}=\mathrm{M}_{3}=2$ or more; $\mathrm{M}_{1}=\mathrm{M}_{2}=$ $\mathrm{M}_{4}=2$ or more and $\mathrm{M}_{2}=\mathrm{M}_{3}=\mathrm{M}_{4}=2$ or more) nineteen performance indicators were validated out of twenty five as mentioned in column number 10 of Table 5 as per the response received from the scientists/faculties. In brief the indicators were faculty associated with the international collaboration in research, per cent of staff involved as principal researcher in external funded project, addressing the current research problem of farmers, recognition in the scientific community of the work produced by university departments, MoU/ MoA and collaboration with the industries, international joint research publications, international research project received, research articles in high impact journals, research impact, research database in university website, number of international awards and prizes won for research work, patent awarded to university, expenditure on research and others as shown in Table 5.

Agricultural Research System of India should be considered under global perspective and its quality should be maintained. For this quality maintaining, a set of performance indicator is identified. These performance indicators will help universities, government or other independent agencies to continuous monitoring of agricultural research of agricultural universities, institutions of ICAR and other agricultural research institutions and organisations.

\section{References}

ISNAR 1987. Report of International Workshop on Agricultural Research Management. 7-11 September 1987, The Hague. The Hague: ISNAR. See pp. 216-217.

Marginson, S. and M. van der Wende. 2007. Globalisation and Higher Education. OECD Education Working Papers, No. 8, OECD Publishing, Paris. http://dx.doi.org/10.1787/173831 738240.

Ranjitha, P. 1998. The Indian agricultural research system: Structure, current policy issues, and future orientation. World Development, 26(6), 1089-1101.

\section{How to cite this article:}

Chandan Kumar Panda, Arun Kumar, Vishal Tripathi and Siya Ram Singh. 2018. Perception of Scientists on Performance Indicators for Monitoring and Evaluation of Agricultural Research System of India. Int.J.Curr.Microbiol.App.Sci. 7(10): 925-929.

doi: https://doi.org/10.20546/ijcmas.2018.710.102 